\title{
BATAS WAKTU KEWENANGAN PENAHANAN DALAM PROSES PENYIDIKAN TINDAK PIDANA NARKOTIKA DI POLRES LABUHANBATU DITINJAU DARI HUKUM
}

\author{
Oleh: \\ Indra Kumalasari M SH, MH*, M. Yusuf Siregar, SHI, MH* \\ * STIH Labuhan Batu \\ Email : indrakumalsarim@gmail.com
}

\begin{abstract}
ABSTRAK
Penelitian ini bertujuan untuk menganalis aspek hukum dasar Batas Waktu Kewenangan Penahanan Dalam Proses Penyidikan Tindak Pidana Narkotika Di Polres Labuhanbatu Ditinjau Dari Hukum. Penelitian ini bersifat Normatif Empiris yakni penelitian dengan melihat kondisi yang ada dilapangan dengan mengkaitkan sumber hukum peraturan - peraturan yang berlaku di Negara Republik Indonesia. Manfaat yang akan diterima dari hasil penelitian ini adalah untuk mengetahui dan menggunakan kajian ini sebagai dasar dan teori dalam hal mengetahui dan menganalisis aspek hukum BATAS WAKTU KEWENANGAN PENAHANAN DALAM PROSES PENYIDIKAN TINDAK PIDANA NARKOTIKA DI POLRES LABUHANBATU DITINJAU DARI HUKUM, kajian penelitian ini juga diharapkan dapat membantu para praktisi hukum khususnya Pengacara untuk mengetahui dan memperkuat kewenangannya dalam menangani perkara hukum yang dihadapkan kepadanya. Hasil penelitian menunjukkan bahwa berdasarkan Undang-Undang No 35 Tahun 2009 ini secara ketentuan hukum telah memberikan kewenangan kepada pihak Kepolisian Republik Indonesia dan Pegawai Negeri Sipil untuk melakukan penyidikan terhadap penyalahgunaan dan peredaran gelap Narkotika dan Prekursor Narkotika. Berdasarkan ketentuam Pasal 75 huruf (g), Pasal 76, Pasal 80, dan Pasal 82 ayat (2) huruf (h) Undang-Undang No 35 Tahun 2009 tentang Narkotika dan ataupun ketentuan pasal yang lain didalam undang-undang ini tidak satupun memberikan kewenangan kepada Pihak Kepolisian Republik Indonesia untuk melakukan penangkapan terhadap Pelaku Tindak Pidana Penyalahgunaan dan peredaran gelap Narkotika dan Prekursor Narkotika. Selanjutnya Berdasarkan Pertimbangan Hukum Hakim Pengadilan Negeri Rantauprapat dalam putusannya Nomor 2 /Pid.Prap/2018/PN Rap terhadap kewenangan Pihak Penyidik dari Kesatuan Narkoba Polres Labuhanbatu dalam Penangkapan dan Penahanan Tindak Pidana Narkotika bahwa secara hukum pihak Kepolisian berwenang untuk melakukan Penangkapan dan Penahanan terhadap orang yang diduga melakukan penyalahgunaan dan peredaran gelap Narkotika dan Prekursor Narkotika paling lama 3 x 24 (tiga kali dua puluh empat) dan dapat diperpanjang paling lama 3 x 24 (tiga kali dua puluh empat) sebagaimana ketentuan Pasal 76 Undang-undang Republik Indonesia Nomor 35 Tahun 2009 Tentang Narkotika.
\end{abstract}

Kata Kunci : Batas Waktu, Kewenangan, Penangkapan \& Penahan.

\section{PENDAHULUAN}

\subsection{Latar Belakang Masalah}

Salah satu tugas Kepolisian yang selalu mendapat perhatian adalah tugas dalam rangka menegakkan hukum. Sebagai penegak hukum, polisi merupakan bagian dari jajaran sub sistem peradilan pidana yang merupakan "pintu gerbang" bagi para pencari keadilan.

Sebagai penegak hukum, tugas kepolisian telah diatur secara tegas dalam ketentuan Pasal 14 ayat 1 Undang-Undang Nomor 2 Tahun 2002 tentang Kepolisian Republik Indonesia. Polisi memiliki tugas pokok yaitu : memelihara keamanan dan ketertiban 
masyarakat; menegakkan hukum; dan memberikan perlindungan, pengayoman, dan pelayanan kepada masyarakat. Dalam melaksanakan tugas pokok ini, maka Polisi Republik Indonesia bertugas :

a. Melaksanakan pengaturan, penjagaan, pengawalan, dan patroli terhadap kegiatan masyarakat dan pemerintah sesuai kebutuhan;

b. Menyelenggarakan segala kegiatan dalam menjamin keamanan, ketertiban, dan kelancaran lalu lintas di jalan;

c. Membina masyarakat untuk meningkatkan partisipasi masyarakat, kesadaran hukum masyarakat serta ketaatan warga masyarakat terhadap hukum dan peraturan perundangundangan;

d. Turut serta dalam pembinaan hukum nasional;

e. Memelihara ketertiban dan menjamin keamanan umum;

f. Melakukan koordinasi, pengawasan, dan pembinaan teknis terhadap kepolisian khusus, penyidik pegawai negeri sipil, dan bentuk-bentuk pengamanan swakarsa;

g. Melakukan penyelidikan dan penyidikan terhadap semua tindak pidana sesuai dengan hukum acara pidana dan peraturan perundang-undangan lainnya;

h. Menyelenggarakan identifikasi kepolisian, kedokteran kepolisian, laboratorium forensik dan psikologi kepolisian untuk kepentingan tugas kepolisian;
Selain ketentuan yang telah di sebutkan di atas, Kepolisian juga berwenang melakukan Penyelidikan. Penyelidikan diartikan sebagai serangkaian tindakan penyelidik untuk mencari dan menemukan suatu keadaan atau peristiwa yang diduga merupakan kejahatan atau tindak pidana guna mendapatkan bukti permulaan yang diperlukan untuk memutuskan apakah diperlukan penyidikan atau tidak sesuai dengan perintah undang-undang.

Wewenang yang dimiliki penyidik, sebagaimana yang disebutkan dalam Pasal 7 Ayat (1) huruf $b$ sampai dengan huruf $j$ KUHAP, yaitu :

a. Menerima laporan atau pengaduan dari seseorang tentang adanya suatu tindak pidana

b. Melakukan tindakan pertama pada saat ditempat kejadian

c. Menyuruh berhenti seseorang tersangka dan memeriksa tanda pengenal diri tersangka

d. Melakukan penangkapan, penahanan, penggeledahan, dan penyitaan

e. Melakukan pemeriksaan dan penyitaan surat

f. Mengambil sidik jari dan memotret seorang

g. Memanggil orang untuk didengar dan diperiksa sebagai tersangka atau saksi

h. Mendatangkan orang ahli yang diperlukan dalam hubungannya dengan pemeriksaan perkara

i. Mengadakan penghentian penyidikan 
j. Mengadakan tindakan lain menurut hukum yang bertanggung jawab.

Penyelidik karena kewajibannya mempunyai wewenang menerima laporan, mencari keterangan dan barang bukti, menyuruh berhenti orang yang di curigai dan menanyakan serta memeriksa tanda pengenal diri, serta mengadakan tindakan lain menurut hukum yang bertanggungjawab.

Peraturan perundang - undangan juga memberikan kewenangan yang luas terhadap pihak penyidik untuk melakukan penangkapan demi kepentingan penyidikan sesuai dengan ketentuan pasal 16 ayat (2) KUHAP, namun untuk menjamin hak-hak asasi tersangka, perintah penangkapan tersebut harus di dasarkan pada bukti permulaan yang cukup. Menurut Surat Keputusan Kepala Kepolisian RI (Kapolri) No Pol. SKEP/04/1/1982, bukti permulaan yang cukup merupakan katerangan dan data yang terkandung dalam dua diantara :
a. Laporan polisi
b. Berita Acara Pemeriksaan Polisi
c. Laporan hasil penyelidikan
d. Keterangan saksi/saksi ahli
e. Barang bukti.

Apabila dalam Penyidikan tidak di temukan bukti yang cukup atau peristiwa tersebut bukanlah peristiwa pidana atau penyidikan dihentikan demi hukum, maka penyidik mengeluarkan Surat Perintah Penghentian Penyidikan. Jika Surat Perintah Penghentian Penyidikan telah diterbitkan, maka penyidik memberitahukan hal itu kepada penuntut umum, tersangka atau keluarganya.
Tindakan penyidik untuk menentukan seseorang sebagai Tersangka merupakan salah satu proses dari sistem penegakan hukum pidana sebagaimana dimaksud dalam KUHAP, oleh karenanya proses tersebut haruslah diikuti dan dijalankan dengan prosedur yang benar sebagaimana diatur dan ditentukan dalam KUHAP atau PerundangUndangan yang berlaku. Artinya, setiap proses yang akan ditempuh haruslah dijalankan secara benar dan tepat sehingga asas Kepastian Hukum dapat terjaga dengan baik dan pada gilirannya hak asasi yang akan dilindungi tetap dapat dipertahankan.

Sebelum dilakukannya proses penyidikan suatu perkara pidana, seyogiyanya penyelidik terlebih dahulu melakukan penyelidikan atas suatu perkara apakah mengandung unsur pidana atau tidak. Pasal 1 ayat (5) KUHAP mengemukakan bahwa Penyelidikan adalah serangkaian tindakan penyelidik untuk mencari dan menemukan suatu peristiwa yang diduga sebagai tindak pidana guna menentukan dapat atau tidaknya dilakukan Penyidikan menurut cara yang diatur dalam undang-undang ini.

Salah satu contoh yang terjadi diwilayah hukum Polres Labuhanbatu yaitu pada Hari Jumat, tanggal 16 Desember 2017 sekitar pukul 20.00 wib, salah satu Rumah Warga Desa Asam Jawa Kecamatan Torgamba Kabupaten Labuhanbatu Selatan didatangi oleh Penyidik dari kesatuan Narkoba Polres Labuhanbatu dengan memperlihatkan Berita 
Acara Pemeriksaan seorang tersangka (yang Identitasnya diketahui bernama Ayu Asmira).

Pada waktu kedatangan Penyidik dari Kesatuan Narkoba Polres Labuhanbatu salah satu Rumah Warga tersebut, Penyidik juga membawa seorang Tersangka (Ayu Asmira) yang berdasarkan hasil Penyidikan menyatakan bahwa Tersangka (Ayu Asmira) mendapatkan Narkotika jenis sabu-sabu dari seorang Warga Desa Asam Jawa Kecamatan Torgamba Kabupaten Labuhanbatu Selatan tersebut. Pada saat dilakukan penggeledahan dan penunjukan rumah oleh pihak kepolisian atas keterangan Tersangka (Ayu Asmira) yang mana berdasarkan keterangan dari penghuni rumah beserta warga yang menyaksikan, Tersangka (Ayu Asmira) terlihat keheranan dan tidak mengenali siapapun sebagai penghuni rumah.

Pemilik rumah (Rahayuni) yang pada saat itu berada di tingkat dua rumah juga sama sekali tidak mengenal seorang Tersangka (Ayu Asmira). Dengan sangat keheranan dan oleh karena pada saat itu Rahayuni didatangi oleh seorang Penyidik perempuan dan menghadapkan Rahayuni kepada seorang tersangka (Ayu Asmira) dengan kondisi meraba dan keheranan seorang Tersangka (Ayu Asmira) menunjuk bahwa ianya mendapatkan Narkotika jenis sabu dari Rahayuni.

Selanjutnya atas tuduhan tersebut, Rahayuni beserta dengan seluruh keluarga yang sama sekali tidak tahu-menahu peristiwa apapun membantah tuduhan tersebut, dan akan tetapi pihak Penyidik Kesatuan Narkoba Polres Labuhanbatu dengan dasar tuduhan tersebut akhirnya melakukan penggeledahan baik itu berupa perintah untuk membuka seluruh pakaian, juga Penggeledahan rumah secara terpaksa (diacak-acak). Pada waktu penggeledahan tersebut, pihak Penyidik Kesatuan Narkoba Polres Labuhanbatu tidak didasari dengan surat Perintah Penggeledahan. Dari hasil penggeledahan tersebut, pihak Penyidik Kesatuan Narkoba Polres Labuhanbatu sama sekali tidak menemukan jenis Narkotika dalam bentuk apapun.

Meskipun tidak menemukan jenis Narkotika dalam bentuk apapun, akan tetapi Pihak Penyidik dari Kesatuan Narkoba Polres Labuhanbatu pada tanggal 16 Desember 2017 tersebut sekitar pukul 22.00 wib atas tuduhan tersangka (Ayu Asmira) tetap membawa sdri. Rahayuni Kepolres Labuhanbatu dan ditahan tanpa ada menerima selembar surat apapun dari penyidik yang diberikan kepada Rahayuni maupun keluarga.

Bahwa selanjutnya keesokan harinya pada hari Sabtu 17 Desember 2017 sekitar pukul 12.00 wib, Tersangka (Ayu Asmira) dipertemukan (dikonfrontasi) kembali oleh Penyidik dengan Rahayuni, dan setelah dilakukan Penyidikan akhirnya Tersangka (Ayu Asmira) mengakui sama sekali tidak mengenal Rahayuni, serta mengakui bahwa Narkotika tersebut didapati Tersangka (Ayu Asmira) dari seorang Pegawai di Tanjung Kusta. Dalam proses Penyidikan tersebut, Penyidik juga telah melakukan Test Urine 
terhadap Rahayuni yang mana berdasarkan hasil test menunjukkan bahwa Urine Rahayuni sama sekali tidak mengandung Narkotika (Negatif).

Bahwa pada saat itu pula Tersangka (Ayu Asmira) meminta maaf kepada Rahayuni, kepada suami dan juga kepada Tim Penasehat Hukum Rahayuni, dan akan tetapi meskipun telah ada proses Penyidikan dan permohonan maaf yang dilakukan oleh Tersangka (Ayu Asmira) kepada Rahayuni, keluarga dan juga Tim Penasehat hukum, dan akan tetapi (Penyidik) dari Kesatuan Narkoba Polres Labuhanbatu tetap melakukan penahanan dengan alasan memiliki kewenangan Penahanan selama 6 hari. Berdasarkan pra penelitian yang dilakukan, Penasehat Hukum Rahayuni telah meminta berulangkali kepada Tim Penyidik dari Kesatuan Narkoba Polres Labuhanbatu agar Rahayuni yang sama sekali tidak terlibat dalam perkara tersebut berdasarkan penyidikan dapat dipulangkan, akan tetapi Penyidik tetap bersikeras masih memiliki kewenangan menahan 3 kali 24 jam sebagaimana ketentuan pasal 76 UU Nomor 35 Tahun 2009 tentang Narkotika.

Bahwa selanjutnya meskipun Tim Penasehat hukum Rahayuni menjelaskan bahwa sudah jelas-jelas Rahayuni tidak ada hubungannya dengan Tersangka (Ayu Asmira), selanjutnya atas dasar permohonan maaf yang dilakukan oleh Tersangka (Ayu Asmira) dengan Rahayuni menunjukkan bahwa rahayuni sama sekali tidak terlibat dalam perkara tersebut, dan bahkan penasehat hukum Rahayuni telah memperlihatkan Ketentuan Pasal 75 dan 76 UU Nomor 35 Tahun 2009 tentang Narkotika, yang pada pokoknya menyatakan bahwa "kewenangan paling lama 3 x 24 (tiga kali dua puluh empat) dan dapat diperpanjang paling lama $3 \times 24$ (tiga kali dua puluh empat) jam adalah kewenangan penyidik BNN, bukan penyidik Kepolisian", namun Penyidik dari Kesatuan Narkoba Polres Labuhanbatu juga menyatakan bahwa hal tersebut juga merupakan kewenangan Kepolisian.

Penangkapan dan penahanan yang tidak dilakukan berdasarkan hukum yang tidak sah yang pada pokoknya tidak sesuai dengan ketentuan formil hukum yang berlaku, jelas menimbulkan hak hukum bagi seseorang khususnya Rahayuni dalam permasalahan yang akan dilakukan penelitian ini telah melakukan upaya hukum berupa koreksi dan/ atau pengujian terhadap keabsahan melalui Lembaga Praperadilan berupa Permohonan Ganti Kerugian atas penangkapan maupun penahanan oleh pihak kepolisian yang menurut Rahayuni selaku Pemohon telah menyalahi ketentuan Pasal 75 dan 76 UU Nomor 35 Tahun 2009 tentang Narkotika, yang pada pokoknya menyatakan bahwa “ Dalam rangka melakukan penyidikan, penyidik BNN berwenang: menangkap dan menahan orang yang diduga melakukan penyalahgunaan dan peredaran gelap Narkotika dan Prekursor Narkotika ( Pasal 75 (g)), kewenangan paling lama $3 \times 24$ (tiga kali dua puluh empat) dan 
dapat diperpanjang paling lama 3 × 24 (tiga kali dua puluh empat) jam adalah kewenangan penyidik BNN (Pasal 76).

Untuk itu dalam upaya mengetahui dan menganalisis aspek hukum dasar dan batas waktu Kewenangan Penyidik kepolisian dalam rangka menangkap dan menahan orang yang diduga melakukan penyalahgunaan dan peredaran gelap Narkotika dan Prekursor Narkotika sebagaimana ketentuan Pasal 75 (g) UU Nomor 35 Tahun 2009 tentang Narkotika yang pada saat diajukannya profosal penelitian ini masih dalam tahap pemeriksaan pada Pengadilan Negeri Rantauprapat, maka Penelitian ini diberi judul "BATAS WAKTU KEWENANGAN PENAHANAN DALAM PROSES PENYIDIKAN TINDAK PIDANA NARKOTIKA DI POLRES LABUHANBATU DITINJAU DARI HUKUM".

\subsection{Rumusan masalah}

Berdasarkan pemaparan uraian yang dikemukakan diatas, menjadi pokok permasalahan yang ingin diteliti dan di bahas dalam penulisan ini adalah sebagai berikut:

1. Bagaimana Ketentuan hukum tentang kewenangan pihak Kepolisian dalam Penyidikan Tindak Pidana Narkotika?

2. Bagaimana landasan hukum kewenangan Pihak Kepolisian dalam Penangkapan dan Penahanan Dalam Proses Penyidikan Tindak Pidana Narkotika?

3. Bagaimana Pertimbangan Hukum Hakim Pengadilan Negeri Rantauprapat terhadap kewenangan Pihak Penyidik dari Kesatuan
Narkoba Polres Labuhanbatu dalam

Penangkapan dan Penahanan Tindak Pidana Narkotika?

\subsection{Tujuan Penelitian}

Sesuai dengan rumusan masalah yang telah dikemukakan maka yang menjadi tujuan dalam penelitian ini adalah sebagai berikut:

1. Untuk mengetahui dan menganalisis Ketentuan hukum tentang kewenangan pihak Kepolisian dalam Penyidikan Tindak Pidana Narkotika.

2. Untuk mengetahui dan menganalisis landasan hukum kewenangan Pihak Kepolisian dalam Penangkapan dan Penahanan Dalam Proses Penyidikan Tindak Pidana Narkotika.

3. Untuk mengetahui dan menganalisis Pertimbangan Hukum Hakim Pengadilan Negeri Rantauprapat terhadap kewenangan Pihak Penyidik dari Kesatuan Narkoba Polres Labuhanbatu dalam Penangkapan dan Penahanan Tindak Pidana Narkotika.

\section{METODE PENELITIAN}

Penelitian ini bersifat Normatif Empiris yaitu penelitian dengan melihat kondisi yang ada dilapangan dengan menkaitkan sumber hukum peraturan-peraturan yang berlaku di Negara Republik Indonesia khususnya berkaitan dengan Narkotika.

\section{PEMBAHASAN}

\subsection{KETENTUAN} HUKUM TENTANG KEWENANGAN PIHAK KEPOLISIAN 


\section{PENYIDIKAN TINDAK PIDANA} NARKOTIKA.

Undang-Undang Nomor 8 Tahun 1981 tentang Hukum Acara Pidana (KUHAP), telah mengatur kewenangan Praperadilan yang terbatas dan tidak seluas seperti Pre Trial Hearing di Amerika maupun Rechter Commisaris di Belanda.

Peraturan perundang - undangan juga memberikan kewenangan yang luas terhadap pihak penyidik untuk melakukan penangkapan demi kepentingan penyidikan sesuai dengan ketentuan pasal 16 ayat (2) KUHAP, namun untuk menjamin hak-hak asasi tersangka, perintah penangkapan tersebut harus di dasarkan pada bukti permulaan yang cukup. Menurut Surat Keputusan Kepala Kepolisian RI (Kapolri) No Pol. SKEP/04/1/1982, bukti permulaan yang cukup merupakan katerangan dan data yang terkandung dalam dua diantara :
a. Laporan polisi
b. Berita Acara Pemeriksaan Polisi
c. Laporan hasil penyelidikan
d. Keterangan saksi/saksi ahli
e. Barang bukti.

Apabila dalam Penyidikan tidak di temukan bukti yang cukup atau peristiwa tersebut bukanlah peristiwa pidana atau penyidikan dihentikan demi hukum, maka penyidik mengeluarkan Surat Perintah Penghentian Penyidikan. Jika Surat Perintah Penghentian Penyidikan telah diterbitkan, maka penyidik memberitahukan hal itu kepada penuntut umum, tersangka atau keluarganya.
Tindakan penyidik untuk menentukan seseorang sebagai Tersangka merupakan salah satu proses dari sistem penegakan hukum pidana sebagaimana dimaksud dalam KUHAP, oleh karenanya proses tersebut haruslah diikuti dan dijalankan dengan prosedur yang benar sebagaimana diatur dan ditentukan dalam KUHAP atau PerundangUndangan yang berlaku. Artinya, setiap proses yang akan ditempuh haruslah dijalankan secara benar dan tepat sehingga asas Kepastian Hukum dapat terjaga dengan baik dan pada gilirannya hak asasi yang akan dilindungi tetap dapat dipertahankan.

Terkait dengan Penyidikan Tindak Pidana Narkotika, Undang-Undang No 35 Tahun 2009 tentang Narkotika telah memberikan pengaturan secara tegas mengenai proses Penyidikan, Penuntutan dan Pemeriksaan di sidang pengadilan tindak pidana narkotika, sebagaimana disebutkan dalam ketentuan Pasal 73 sampai dengan Pasal 103 Undang-Undang No 35 Tahun 2009 tentang Narkotika. Dalam setiap rangkaian penanganan kasus narkotika, proses Penyidikan adalah proses yang paling utama dalam memberantas penyalahgunaan Narkotika. Hal ini dikarenakan bahwa penyidikan merupakan suatu proses pengumpulan bukti-bukti yang dapat menentukan siapa tersangkanya, pada proses penyidikanlah dapat dikumpulan barang bukti yang dapat digunakan dalam membuktikan kejahatan dalam penggunaan narkotika. Selain itu pada tahap ini pulalah dapat diketahui 
status tersangka sebagai pemakai atau pengedar.

Pasal 81 Undang-Undang No 35 Tahun 2009 mengemukakan bahwa Penyidik Kepolisian Negara Republik Indonesia dan penyidik BNN berwenang melakukan penyidikan terhadap penyalahgunaan dan peredaran gelap Narkotika dan Prekursor Narkotika berdasarkan Undang-Undang ini.

Dengan demikian, berdasarkan UndangUndang No 35 Tahun 2009 ini secara ketentuan hukum telah memberikan kewenangan kepada pihak Kepolisian Republik Indonesia dan Pegawai Negeri Sipil untuk melakukan penyidikan terhadap penyalahgunaan dan peredaran gelap Narkotika dan Prekursor Narkotika.

\subsection{KEWENANGAN PIHAK KEPOLISIAN}

\section{DALAM PENANGKAPAN DAN} PENAHANAN DALAM PROSES PENYIDIKAN TINDAK PIDANA NARKOTIKA.

Berbicara mengenai Penangkapan dan atau menangkap serta menahan pelaku Penyalahgunaan dan peredaran gelap Narkotika dan Prekursor Narkotika hanya didapati didalam ketentuam Pasal 75 huruf (g), Pasal 76, Pasal 80, dan Pasal 82 ayat (2) huruf (h) Undang-Undang No 35 Tahun 2009 tentang Narkotika.

Dalam ketentuan Pasal 75 huruf (g), pasal 82 Undang-Undang No 35 Tahun 2009 tentang Narkotika meberikan redaksi "Dalam rangka melakukan penyidikan, penyidik $\mathrm{BNN}$ berwenang: (g) menangkap dan menahan orang yang diduga melakukan penyalahgunaan dan peredaran gelap Narkotika dan Prekursor Narkotika;

Selanjutnya Pasal 75 huruf (g), pasal 82 Undang-Undang No 35 Tahun 2009 tentang Narkotika mengemukakan bahwa “(1) Pelaksanaan kewenangan Penangkapan sebagaimana dimaksud dalam Pasal 75 huruf $g$ dilakukan paling lama 3 x 24 (Tiga Kali Dua Puluh Empat) Jam terhitung sejak surat Penangkapan diterima Penyidik.

Penangkapan sebagaimana dimaksud pada ayat (1) dapat diperpanjang paling lama 3 x 24 (tiga kali dua puluh empat) Jam".

Pasal 80 Undang-Undang No 35 Tahun 2009 tentang Narkotika juga kembali memberikan penegasan bahwa Penyidik BNN sebagaimana dimaksud dalam Pasal 75, juga berwenang: meminta bantuan interpol Indonesia atau instansi penegak hukum negara lain untuk melakukan pencarian, penangkapan, dan penyitaan barang bukti di luar negeri.

Pasal 82 ayat (2) huruf (h) UndangUndang No 35 Tahun 2009 tentang Narkotika juga secara redaksi memaparkan bahwa Penyidik pegawai negeri sipil tertentu sebagaimana dimaksud pada ayat (1) di lingkungan kementerian atau lembaga pemerintah non kementerian yang lingkup tugas dan tanggung jawabnya di bidang Narkotika dan Prekursor Narkotika berwenang: (h) menangkap orang yang diduga melakukan penyalahgunaan Narkotika dan Prekursor Narkotika. 
Jika ditelaah secara teliti bahwa berdasarkan ketentuam Pasal 75 huruf (g), Pasal 76, Pasal 80, dan Pasal 82 ayat (2) huruf (h) Undang-Undang No 35 Tahun 2009 tentang Narkotika dan ataupun ketentuan pasal yang lain didalam undang-undang ini tidak satupun memberikan kewenangan kepada Pihak Kepolisian Republik Indonesia untuk melakukan penangkapan terhadap Pelaku Tindak Pidana Penyalahgunaan dan peredaran gelap Narkotika dan Prekursor Narkotika.

Selanjutnya berbicara mengenai tentang Tugas dan Wewenang, Pasal 70 UndangUndang No 35 Tahun 2009 tentang Narkotika menegaskan bahwa BNN mempunyai tugas:

a) menyusun dan melaksanakan kebijakan nasional mengenai pencegahan dan pemberantasan penyalahgunaan dan peredaran gelap Narkotika dan Prekursor Narkotika;

b) mencegah dan memberantas penyalahgunaan dan peredaran gelap Narkotika dan Prekursor Narkotika;

c) berkoordinasi dengan Kepala Kepolisian Negara Republik Indonesia dalam pencegahan dan pemberantasan penyalahgunaan dan peredaran gelap Narkotika dan Prekursor Narkotika;

3.3. PERTIMBANGAN HUKUM HAKIM PENGADILAN

NEGERI

RANTAUPRAPAT TERHADAP

KEWENANGAN PIHAK PENYIDIK

DARI KESATUAN NARKOBA POLRES LABUHANBATU DALAM
PENANGKAPAN DAN PENAHANAN TINDAK PIDANA NARKOTIKA

Dalam kasus yang telah dijadikan sebagai objek penelitian ini sebagaimana yang telah disebutkan dalam pengantar/latar belakang masalah, telah dilakukan pengujian melalui mekanisme Permohonan Pra Peradilan yang ditujukan kepada Pengadilan Negeri Rantauprapat.

Penangkapan dan penahanan yang tidak dilakukan berdasarkan hukum yang tidak sah yang pada pokoknya tidak sesuai dengan ketentuan formil hukum yang berlaku, jelas menimbulkan hak hukum bagi seseorang khususnya Rahayuni dalam permasalahan yang telah dilakukan penelitian ini.

Berdasarkan upaya hukum berupa koreksi dan/ atau pengujian terhadap keabsahan melalui Lembaga Praperadilan berupa Permohonan Ganti Kerugian atas penangkapan maupun penahanan oleh pihak kepolisian yang menurut Rahayuni selaku Pemohon telah menyalahi ketentuan Pasal 75 dan 76 UU Nomor 35 Tahun 2009 tentang Narkotika, yang pada pokoknya menyatakan bahwa " Dalam rangka melakukan penyidikan, penyidik BNN berwenang: menangkap dan menahan orang yang diduga melakukan penyalahgunaan dan peredaran gelap Narkotika dan Prekursor Narkotika ( Pasal 75 (g)), kewenangan paling lama 3 x 24 (tiga kali dua puluh empat) dan dapat diperpanjang paling lama 3 × 24 (tiga kali dua puluh empat) jam adalah kewenangan penyidik BNN (Pasal 76). 
Didalam posita permohonan pra peradilan yang telah diajukan oleh rahayuni melalui kuasa hukumnya berpandangan bahwa sangat cukup jelas, bahwa Penangkapan, penggeledahan dan penyitaan Handphone terhadap diri Pemohon yang dilakukan Termohon terhadap diri Pemohon dan keluarga Pemohon, tidak berdasarkan Bukti Permulaan Yang Cukup. Oleh karena itu, Termohon telah melanggar ketentuan Pasal 17 KUHAP (undang-undang No. 8 tahun 1981).

Bahwa sebagai akibat dari perbuatan yang dilakukan Termohon sebagaimana dikemukakan diatas, telah menimbulkan kerugian Materiil maupun Immateril Pemohon sebesar Rp. 600.900.000,- (Enam Ratus Juta Sembilan Ratus Ribu Rupiah) dengan rincian;

\section{Kerugian MATERIIL :}

a. Kerugian Pokok berupa biaya jasa Pengacara, sebesar Rp. 100.000.000,(Seratus juta rupiah)

b. Kerugian Pemohon atas keuntungan yang diharapkan seandainya Pemohon bekerja selama tiga hari pada saat dilakukannya penahanan Rp. 900.000,(Sembilan ratus ribu rupiah); -

c. Bahwa apabila dijumlahkan, maka kerugian Penggugat secara materiil adalah berjumlah Rp. 100.900.000,(seratus juta sembilan ratus ribu rupiah)

\section{Kerugian IMMATERIIL :}

sebagai akibat dari perbuatan yang dilakukan Termohon sebagaimana dikemukakan diatas, telah menimbulkan kerugian bagi pemohon, baik materil maupun immaterial yang tidak dapat diukur atau dinilai dengan uang dalam kaitannya dengan Hak Azasi Pemohon yang tidak diperlakukan sesuai dengan hukum yang berlaku. Oleh karena itu, serta tercemarnya nama baik Pemohon pada lingkungan tempat tinggal dan pekerjaan adalah patut dan beralasan secara hukum untuk menghukum Termohon membayar ganti rugi kepada Pemohon sebesar Rp. 500.000.000.- (lima ratus juta rupiah) sekaligus dan seketika;

Menurur Pemohon Kerugian MATERIL dan IMMATERIIL apabila di jumlahkan seluruhnya sebesar Rp. $100.900 .000+$ Rp.500.000.000 = Rp. 600.900.000,- (Enam Ratus Juta Sembilan Ratus Ribu Rupiah);

Selanjutnya didalam petitum Permohonan Pemohon memohon agar Majelis Hakim Pengadilan Negeri Rantauprapat Qq. Majelis Hakim yang memeriksa, mengadili perkara Pra Peradilan ini menjatuhkan Putusan sebagai berikut:

1. Menyatakan menerima dan mengabulkan permohonan Pemohon untuk seluruhnya;

2. Menyatakan bahwa perbuatan Termohon yang melakukan Penangkapan dan Penahanan tanpa prosedur adalah cacat yuridis/bertentangan dengan hukum;

3. Memulihkan harkat martabat dan nama baik Pemohon;

4. Menghukum Termohon untuk membayar ganti Kerugian MATERIL dan IMMATERIIL apabila di jumlahkan 
seluruhnya sebesar Rp. 100.900.000 + Rp.500.000.000 =Rp. 600.900.000,- $($ Enam Ratus Juta Sembilan Ratus Ribu Rupiah) seketika sejak Putusan ini berkekuatan hukum tetap;

5. Menghukum Termohon untuk membayar biaya perkara yang timbul dalam perkara aquo.

Berdasarkan hasil Penelitian yang telah dilakukan yang mana pertimbangan hakim dalam putusan Pengadilan Negeri Rantauprapat Nomor 2 /Pid.Prap/2018/PN Rap mengemukakan bahwa mengingat asas lex specialis derogat legi generalis mengandung makna, bahwa aturan hukum yang khusus akan mengesampingkan aturan hukum yang lebih umum, tindak pidana Narkotika yang terdapat di dalam KUHP tidak berlaku lagi sepanjang yang sudah diatur dalam Undang-Undang Republik Indonesia Nomor 35 Tahun 2009 tentang Narkotika;

Majelis Hakim Pengadilan Negeri Rantauprapat berpendapat bahwa Penyidik Polri berwenang melakukan penangkapan paling lama $3 \times 24$ (tiga kali dua puluh empat) jam sebagaimana termaktub dalam Pasal 76 Ayat (1) jo Pasal 75 huruf (g) Undang-undang Republik Indonesia Nomor 35 Tahun 2009 Tentang Narkotika. Dalam pertimbangannya pula mengemukakan bahwa Penangkapan yang dilakukan oleh Termohon terhadap Pemohon dalam perkara yang telah diputus oleh Pengadilan Negeri Rantauprapat Nomor 2 /Pid.Prap/2018/PN Rap sebagaimana Surat Perintah Penangkapan Nomor: SP-
Kap/397/XII/2017/ Sat Res Narkoba tanggal 15 Desember 2017 dan Berita Acara Penangkapan tanggal 15 Desember 2017 adalah sah menurut hukum.

Bahwa dengan demikian peneliti berkesimpulan bahwa pihak Kepolisian berwenang untuk melakukan Penangkapan dan Penahanan terhadap orang yang diduga melakukan penyalahgunaan dan peredaran gelap Narkotika dan Prekursor Narkotika paling lama 3 x 24 (tiga kali dua puluh empat) dan dapat diperpanjang paling lama 3 x 24 (tiga kali dua puluh empat) sebagaimana ketentuan Pasal 76 Undang-undang Republik Indonesia Nomor 35 Tahun 2009 Tentang Narkotika

\section{KESIMPULAN DAN SARAN}

\subsection{Kesimpulan}

Berdasarkan uraian dari bab-bab sebelumnya, dapat diambil kesimpulan sebagai berikut:

1. Hasil penelitian menunjukkan bahwa berdasarkan Undang-Undang No 35 Tahun 2009 ini secara ketentuan hukum telah memberikan kewenangan kepada pihak Kepolisian Republik Indonesia dan Pegawai Negeri Sipil untuk melakukan penyidikan terhadap penyalahgunaan dan peredaran gelap Narkotika dan Prekursor Narkotika.

2. Berdasarkan ketentuam Pasal 75 huruf (g), Pasal 76, Pasal 80, dan Pasal 82 ayat (2) huruf (h) Undang-Undang No 35 Tahun 
2009 tentang Narkotika dan ataupun ketentuan pasal yang lain didalam undangundang ini tidak satupun memberikan kewenangan kepada Pihak Kepolisian Republik Indonesia untuk melakukan penangkapan terhadap Pelaku Tindak Pidana Penyalahgunaan dan peredaran gelap Narkotika dan Prekursor Narkotika.

3. Berdasarkan Pertimbangan Hukum Hakim Pengadilan Negeri Rantauprapat dalam putusannya Nomor 2 /Pid.Prap/2018/PN Rap terhadap kewenangan Pihak Penyidik dari Kesatuan Narkoba Polres Labuhanbatu dalam Penangkapan dan Penahanan Tindak Pidana Narkotika bahwa secara hukum pihak Kepolisian berwenang untuk melakukan Penangkapan dan Penahanan terhadap orang yang diduga melakukan penyalahgunaan dan peredaran gelap Narkotika dan Prekursor Narkotika paling lama $3 \times 24$ (tiga kali dua puluh empat) dan dapat diperpanjang paling lama 3 x 24 (tiga kali dua puluh empat) sebagaimana ketentuan Pasal 76 Undang-undang Republik Indonesia Nomor 35 Tahun 2009 Tentang Narkotika

\subsection{Saran}

Berdasarkan Kesimpulan di atas, maka penulis memberikan saran-saran sebagai berikut :

1) Perlu diperhatikan oleh pemerintah tentang Peraturan perundang-Undangan mengenai kewenangan kepada Pihak Kepolisian Republik Indonesia untuk melakukan penangkapan terhadap Pelaku Tindak Pidana Penyalahgunaan dan peredaran gelap Narkotika dan Prekursor Narkotika.

2) Diharapkan kepada seluruh aparat penegak hukum khususnya Kepolisian, Jaksa Dan Hakim di Indonesia agar terlebih dahulu menggali hukum sebelum mengadili suatu perkara yang dihadapkan kepadanya.

\section{DAFTAR PUSTAKA}

\section{Buku}

Achmad Ali, 2008, Menguak Tabir Hukum, Bogor: Ghalia Indonesia Sukarno Aburaera. 2012. Kekuasaan Kehakiman Indonesia.Makassar : Arus Timur

Ahmad Rivai, 2010, Penemuan Hukum Oleh Hakim dalam perspektif hukum progresif, Jakarta: Sinar Grafika

And Sofyan.2013.Hukum Acara Pidana suatu pengantar. Yogyakarta: Rangkang education

Andi Hamzah, 2013, Hukum Acara Pidana Indonesia, Edisi Kedua, cet.ketujuh, Jakarta: Sinar Grafika

Atmasasmita, Romli. 1996, Sistem Peradilan Pidana Perspektif Eksistensialisme dan Abolisionisme, Bina Cipta, Bandung.

Hamzah, A. 2010. Hukum Acara Pidana Indonesia. Jakarta : Sinar Grafika

Idul Rishan. 2013. Komisi Yudisial Suatu Upaya Mewujudkan Wibawa Peradilan. Jakarta: Genta Press

Jasim Hamidi, 2005 Hermeneutika Hukum, Teori Penemuan Hukum Baru dengan Interpretasi Teks, Yogyakarta: UII Pres

\section{Kuffal, H.M.A. 2003. Penerapan KUHAP dalam Praktik Hukum. Malang : Universitas Muhammadiyah Malang.}


Lilik Mulyadi, 2007, Hukum Acara Pidana normatif, teoritis, praktik dan permasalahannya, Bandung : Alumni

M. Yahya Harahap, 2000, Pembahasan Permasalahan dan Penerapan KUHAP, Jakarta: Sinar Grafika

Marpaung, Leden. 2009. Proses Penanganan Perkara Pidana (penyelidikan \& penyidikan), Sinar Grafika, Jakarta.

Muhammad, Rusli. 2011, Sistem Peradilan Pidana Indonesia, UII Press, Yogyakarta.

Nawawi Arief, Barda. 1996, Bunga Rampai Kebijakan Hukum Pidana, PT. Citra Aditya, Bandung.

Pontang Moerad, B.M., 2005, Pembentukan Hukum Melalui Putusan Pengadilan dalam Perkara Pidana,Bandung : Alumni

S. Tanubroto, 1983, Peranan Praperadilan Dalam Hukum Acara Pidana, Bandung: Alumni
Sudikno Mertokusumo dan A. Pitlo, 1993, Bab-Bab Tentang Penemuan Hukum, Bandung: Citra Aditya Bakti

Sudikno Mertokusumo, 1996, Penemuan Hukum suatu pengantar, Yogyakarta : Liberty

Utrecht, E. Hukum Pidana II, Surabaya : Pustaka Tinta Mas, 2000.

Waluyo, B. 2000. Pidana dan Pemidanaan. Jakarta : Sinar Grafika.

\section{Peraturan Perundang-Undangan :}

Kitab Undang-Undang Hukum Pidana (KUHP)

Kitab Undang-Undang Hukum Acara Pidana (KUHAP)

Undang-Undang Nomor 2 Tahun 2002 tentang Kepolisian Republik Indonesia

Undang-Undang Nomor 30 Tahun 2014 tentang Administrasi Pemerintahan

Undang-Undang Nomor 35 Tahun 2009 tentang Administrasi Narkotika

\section{Putusan :}

Putusan Pengadilan Negeri Rantauprapat

Nomor 2 /Pid.Prap/2018/PN Rap 